\title{
Pengaruh Gaya Kepemimpinan dan Motivasi Kerja Terhadap Prestasi Kerja Pegawai Kantor Kecamatan Rawas Ulu Kabupaten Musi Rawas Utara
}

\author{
Arrosidin Misdiono ${ }^{1}$, Suhada ${ }^{2}$, Tri Sinarti ${ }^{3}$ \\ ${ }^{1}$ Manajemen Fakultas Ekonomi Universitas PGRI Palembang, arrosidin0810@gmail.com \\ ${ }^{2}$ Manajemen, Fakultas Ekonomi Universitas PGRI Palembang, Suhadaahmadmadjid@gmail.com \\ ${ }^{3}$ Manajemen, Fakultas Ekonomi Universitas PGRI Palembang, trisinarti1976@gmail.com
}

\begin{abstract}
ABSTRAK
Penelitian ini bertujuan untuk mengetahui pengaruh Gaya Kepemimpinan dan Motivasi Kerja terhadap Prestasi Kerja Pegawai Kantor Kecamatan Rawas Ulu. Metode yang digunakan dalam penelitian ini adalah metode kuantitatif. Dengan jumlah populasi yang diteliti adalah 34 pegawai. Teknik pengambilan sampel adalah sampel jenuh dengan jumlah sampel 34 pegawai. Teknik analisis data yang digunakan dalam penelitian ini adalah analisis regresi linier berganda, analisis koefisien korelasi, analisis koefisien determinasi, uji $\mathrm{F}$ dan uji t dengan menggunakan program softwarespss 22 for windows. Hasil pembahasan dapat diketahui bahwa secara parsial nilai signifikan untuk variabel Gaya Kepemimpinan $\left(X_{1}\right)$ sebesar $0,037<0,05$ sehingga $H_{0}$ ditolak, $H_{a}$ diterima, artinya Gaya Kepemimpinan $\left(X_{1}\right)$ berpengaruh signifikan terhadap Prestasi Kerja $(\mathrm{Y})$. Dan untuk hasil nilai signifikan dari Motivasi Kerja $\left(\mathrm{X}_{2}\right)$ sebesar $0,032<0,05$ sehingga $\mathrm{H}_{\circ}$ ditolak, $\mathrm{H}_{a}$ diterima artinya terdapat pengaruh signifikan Motivasi kerja $\left(\mathrm{X}_{2}\right)$ terhadap Prestasi Kerja $(\mathrm{Y})$ pegawai Kantor Kecamatan Rawas Ulu. Sedangkan secara simultan hasil penelitian menunjukkan bahwa nilai signifikan untuk Variabel Gaya Kepemimpinan $\left(\mathrm{X}_{1}\right)$ dan Motivasi Kerja $\left(X_{2}\right)$ sebesar $0,002<0,05$ sehingga $H_{0}$ ditolak, $H_{a}$ diterima berarti terdapat pengaruh signifikan Antara Gaya Kepemimpinan $\left(X_{1}\right)$ dan Motivasi Kerja $\left(X_{2}\right)$ secara bersama-sama terhadap Prestasi Kerja $(Y)$ Pegawai Kantor Kecamatan Rawas Ulu.
\end{abstract}

Kata kunci: gaya kepemimpinan, motivasi kerja dan prestasi kerja

\begin{abstract}
This study aims to determine the effect of Leadership Style and Work Motivation on Work Performance of Rawas Ulu District Office Employees. The method used in this study is a quantitative method. With the number of population studied is 34 employees. The sampling technique is a saturated sample with a total sample of 34 employees. The data analysis technique used in this study is multiple linear regression analysis, correlation coefficient analysis, coefficient of determination analysis, $F$ test and $t$ test using the software program SPSS 22 for Windows. The results of the discussion can be seen that partially the significant value for the Leadership Style variable $\left(X_{1}\right)$ is $0.037<0.05$ so Ho is rejected, Ha is accepted, meaning that Leadership Style $\left(X_{1}\right)$ has a significant effect on Work Performance ( $Y$ ). And for the results of the significant value of Work Motivation $\left(X_{2}\right)$ of $0.032<0.05$ so Ho is rejected, Ha is accepted, meaning that there is a significant effect of Work Motivation $\left(\mathrm{X}_{2}\right)$ on Work Performance $(Y)$ of Rawas Ulu District Office employees. Meanwhile, simultaneously the results of the study show that the significant value for the Leadership Style Variable $\left(X_{1}\right)$ and Work Motivation $\left(X_{2}\right)$ is 0,002 <0,05 so that Ho is rejected, Ha is accepted, meaning that there is a significant influence between Leadership Style $\left(X_{1}\right)$ and Work Motivation $\left(X_{2}\right)$. together on the work achievement $(Y)$ of the Rawas Ulu District Office Employee
\end{abstract}

Keyword : leadership style, work motivation and work performance

\section{A. PENDAhULUAN}

Sumber daya manusia merupakan bagian terpenting suatu organisasi dalam mencapai tujuannya. Organisasi sendiri tentunya dapat tercapai jika pemimpin dapat melaksanakan fungsi manajemen dengan baik, mengelolah aktivitas manajemen bawahan dan mampu memadukan kemampuan pegawainya dengan kebutuan organisasi. 
Dalam setiap organisasi tentu mempunyai seorang pemimpin yang memiliki pola kepemimpinan tersendiri baik dalam menggerakkan dan memberikan arahan setiap pegawainya. Pimpinan yang efektif dalam menerapkan gaya kepemimpinan tentu harus memahami siapa bawahan yang dipimpinnya, mengerti kekuatan dan kelemahan yang mereka miliki. Dengan gaya kepemimpinannya, maka seorang pemimpin harus dapat menjadi motivasi untuk melaksanakan tugasnya dengan baik.

Memotivasi seseorang merupakan kunci keberhasilan seorang pimpinan pada suatu organisasi sebagai penunjang kinerja pegawai. Dengan tanpa adanya motivasi seorang bawahan tidak memiliki semangat saat melakukan pekerjaan. Motivasi sangat dibutuhkan, karena jika seseorang termotivasi biasanya mempunyai kewajiban tinggi pada pekerjaannya, serta memberikan hasil kerja yang maksimal. Untuk itu, seorang pemimpin dapat berpartisipasi langsung dalam meningkatkan motivasi kerja pegawai, diantaranya memberikan penghargaan atas prestasi kerja yang dapat membuat karyawan merasa dihargai jerih payahnya.

Prestasi kerja sendiri merupakan hasil pencapaian pengembangan dari sumber daya manusia yang berkualitas, mempunyai pengetahuan, kemampuan, sikap dan perilaku yang terus berkembang yang diukur melalui standar atau kriteria yang telah diterapkan organisasi. Karena ukuran terakhir keberhasilan suatu departemennya, itu adanya penilaian prestasi kerja.

Dari hasil observasi yang dilakukan oleh peneliti dengan beberapa pegawai yang ada di Kantor Kecamatan Rawas Ulu, diketahui bahwa adanya permasalahan yang berhubungan dengan gaya kepemimpinan yang kurang baik. Terutama pada pola komunikasi yang kurang jelas, yang dapat membuat beberapa pegawai salah mengartikan dengan apa yang diperintahkanya. Dengan adanya permasalahan tersebut, dapat menyebabkan kesenjangan antara pegawai dengan pimpinan sehingga dapat menurunkan hasil prestasi kerja pegawainya

Selain faktor gaya kepemimpinan, rendanya motivasi juga dapat menyebabkan menurunnya prestasi kerja pegawai pada instansi tersebut. Motivasi kerja yang rendah dapat disebabkan karena kurang baiknya hubungan pegawai dengan rekan kerjanya, sering munculnya kecemburuan diantara pegawai akibat adanya perbedaan gaji yang diterima oleh pegawai. Faktor kondisi kerja juga dapat mempengaruhi motivasi kerja. Dengan kondisi ruangan yang kurang nyaman yang disediakan oleh instansi merupakan salah satu penyebab kurang semangatnya pegawai dalam bekerja terkhusus untuk pegawai yang bekerja didalam ruangan.

Penelitian mengenai pengaruh gaya kepemimpinan dan motivasi kerja terhadap prestasi kerja pegawai telah banyak dilakukan sebelumnya. Seperti penelitian yang dilakukan oleh Widiartana (2016) yang memperlihatkan hasil bahwa gaya kepemimpinan dan motivasi kerja secara simultan berpengaruh terhadap prestasi kerja karyawan. Dan penelitian lain yang dilakukan oleh Liawati (2013) memperlihatkan hasil bahwa antara gaya kepemimpinan dan motivasi kerja secara secara simultan berpengaruh signifikan terhadap prestasi kerja pegawai.

\section{B. KAJIAN TEORI}

1. Gaya Kepemimpinan

a. Pengertian Gaya Kepemimpinan

Menurut Mulyadi (2015:60) gaya kepemimpinan merupakan sebuah penunjukan perilaku seorang pemimpin yang menjadi ciri khusus untuk dapat mempengaruhi karyawan mencapai tujuan organisasi. Menurut Rivai (2017:42) gaya kepemimpinan merupakan karakter pemimpin untuk mempengaruhi karyawan sesuai 
sasaran tujuan organisasi. Menurut Busro (2018:266) gaya kepemimpinan merupakan cara pimpinan untuk dapat memengaruhi karyawan agar mau melakukan pekerjaan sesuai perintah pemimpin tanpa merasakan tekanan saat menggapai tujuannya.

b. Macam-Macam Gaya Kepemimpinan

Menurut Busro (2018:299) ada beberapa gaya kepemimpinan yaitu :

1) Gaya kepemimpinan otokratis

Pimpinan yang mempunyai kuasa penuh terhadap organisasi dan tidak memberikan kesempatan untuk bawahan menunjukkan keinginan tujuan individu terhadap tujuan organisasi.

2) Gaya kepemimpinan militeristik

Pimpinan yang selalu memberikan tugas sesuai keahlian yang dimiliki dan menerapkan kedisiplinan untuk setiap karyawannya.

3) Gaya kepemimpinan paternalistik

Pimpinan yang memberikan perlindungan karena dianggap tidak dapat mengambil keputusan secara individu dan selalu membutuhkan pimpinan.

4) Gaya kepemimpinan karismatik

Pimpinan memberikan daya pikat yang luas dan selalu melakukan pelatihan untuk setiap karyawan yang setia pada pemimpinnya.

5) Gaya kepemimpinan demokratis

Yang selalu melakukan diskusi dan kerja sama tim pada suatu organisasi. Sehingga pimpinan mampu mengatur dan memberikan pengawasan terhadap karyawannya.

c. Indikator Gaya Kepemimpinan

Menurut Kartono (2016:34) ada beberapa indikator yaitu :

1) Kemampuan mengambil keputusan

Keputusan yang dilakukan secara sistematis dan pengambilan tindakan dengan perhitungan paling tepat.

2) Kemampuan memotivasi.

Memotivasi seseorang agar mau menunjukkan keahliannya untuk sebagian kegiatan yang menjadi tanggung jawabnya.

3) Kemampuan berkomunikasi.

Kemampuan dalam memberikan pesan, saran dan pikiran terhadap orang lain baik secara berhadapan langsung atau tidak.

4) Kemampuan mengendalikan bawahan.

Kemapuan selalu mempengaruhi bawahanya untuk mengikuti keinginan pimpinan agar tugas yang diberikan diselesaikan dengan baik.

5) Kemampuan mengendalikan emosional.

Kemampuan mengendalikan emosi merupakan salah satu yang menjadi keberhasilan hidup seseorang.

\section{Motivasi kerja}

a. Pengertian Motivasi Kerja

Menurut Rivai (2017:837) motivasi ialah sikap seseorang untuk dapat mempengaruhi seseorang pada. Menurut Hasibuan (2017:141) motivasi merupakan merupakan hal yang menyebabkan, menyalurkan, dan mendukung perilaku manusia supaya bekerja giat dan antusias mencapai hasil yang maksimal. Menurut Kholilah 
(2018:57) motivasi merupakan faktor dari seseorang yang mengarahkan perilaku untuk memenuhi tujuan tertentu.

b. Jenis-Jenis Motivasi Kerja

Menurut Winardi (2014:5) jenis motivasi dibagi menjadi beberapa bagian, ada motivasi positif dan negatif yaitu :

1) Motivasi positif, pemberian penghargaan berupa gaji / insentif ketika bawahan telah memenuhi standar yang telah ditentukan.

2) Motivasi negatif, sering dikatakan tongkat pemukul yang dilakukan dengan memberikan teguran keras bagi karyawan yang melaukan kesalahan.

c. Prinsip-Prinsip Motivasi

Menurut Mangkunegara dalam Busro (2020:51) ada prinsip untuk motivasi kerja karyawannya yaitu :

1) Prinsip Partisipasi

Berpartisipasi saat melaksanakan motivasi dalam pencapaian tujuan seorang pimpinan

2) Prinsip komunikasi

Berkomunikasi yang memiliki hubungan dengan tujuan dari pekerjaan, dengan informasi sesuai fakta sehingga karyawan mudah untuk memahaminya.

3) Prinsip mengakui adil terhadap bawahan

Pimpinan menjelaskan sebagian pegawai memiliki wewenang saat menjelaskan itu semua akan lebih memudahkan karyawan termotivasi.

4) Pendelegasian wewenang

Pemimpin memberikan wewenang untuk karyawan saat mengambil keputusan melakukan pekerjaannya.

5) Pemberian perhatian

Pimpinan selalu memberi wewenang untuk bawahan saat mengambil keputusan.

d. Indikator-Indikator Motivasi Kerja

Indikator motivasi kerja menurut Syahyuti dalam Puspitasari (2014:15):

1) Dorongan mencapai tujuan

seseorang termotivasi dan dirinya mempuyai dorongan dari seseorang untuk bekerja lebih maksimal.

2) Semangat kerja

Semangat kerja merupakan kebahagiaan yang memberikan dorongan kepada seseorang dalam bekerja dan lebih konsekuensi saat mencapai tujuan yang diterapkan oleh perusahaan.

3) Inisiatif dan kreatifitas

Inisitif artinya sebagian kualitas seseorang karyawan menjalankan pekerjaan. Kreatifitas merupakan seseorang menciptakan sesuatu yang baru.

4) Rasa tanggung jawab

Kesadaran karyawan dalam menyelesaikan pekerjaan dengan tepat waktu.

\section{Prestasi Kerja}

a. Pengertian Prestasi Kerja

Menurut Sikula (2015:57) prestasi kerja ialah suatu penilaian yang teratur pada pekerjaan yang sudah dilaksanakan seorang karyawan dan untuk ditingkatkan. Menurut Desler (2015:523) prestasi kerja merupakan kesan nyata seorang bawahan 
dan mengkaitkan beberapa bentuk kualitas sesuai standar yang ditetapkan. Menurut Yoder (2015:43) prestasi kerja merupakan prosedur yang formal dilakukan dalam organisasi untuk mengevaluasi pegawai dan sumbangan kepentingan bagi pegawai.

b. Manfaat Prestasi Kerja

Menurut Siagian (2015:227) ada beberapa penilaian kinerja bermanfaat untuk beberapa kepentingan yaitu:

1) Memotivasi dalam meningkatkan prestasi kerja

2) Sebagai materi pengambilan hasil ketika memberikan balasan.

3) Untuk kebutuhan pembaruan karyawan seperti peningkatan, ganti peran.

4) Dalam pengembangan kemampuan dapat dilakukan dengan pelatihan dan pendidikan yang baik.

c. Tujuan Prestasi Kerja

Tujuan penilaian dan pencatatan sangat berarti dan menurut Ranupandojo dan Husnan (2011:25) :

1) Perkiraan dari kesuksesan seseorang dapat diukur prestasi kerjanya sudah sejauh mana.

2) Melihat kemajuan dalam training kerja.

3) Sebagai bahan mempertimbangkan peningkatan untuk karyawan yang terkait.

d. Indikator Prestasi Kerja

Menurut Hasibuan (2017:130) ada beberapa Indikator yang mempengaruhi prestasi kerja antara lain :

1) Kualitas kerja.

Indikator ini antara lain ketepatan peneliti, kerapian dalam kerjaan, menggunakan dan merawat alat kerja.

2) Kuantitas.

Jumlah hasil dalam konteks nilai uang, jumlah penyelesaian siklus aktivitas dan jumlah unit.

3) Jangka waktu.

Tingkat penyesuaian kegiatan yang dikerjakan atau hasil yang dicapai dengan tingkat waktu tersingkat yang diharapkan sehingga dapat memaksimalkan pemanfaatan waktu kegiatan lainnya.

4) Efektifitas biaya

Tingkat pemaksimalan sumber daya organisasi untuk memperoleh hasil terbanyak atau menekan kerugian.

\section{Kerangka Pemikiran}

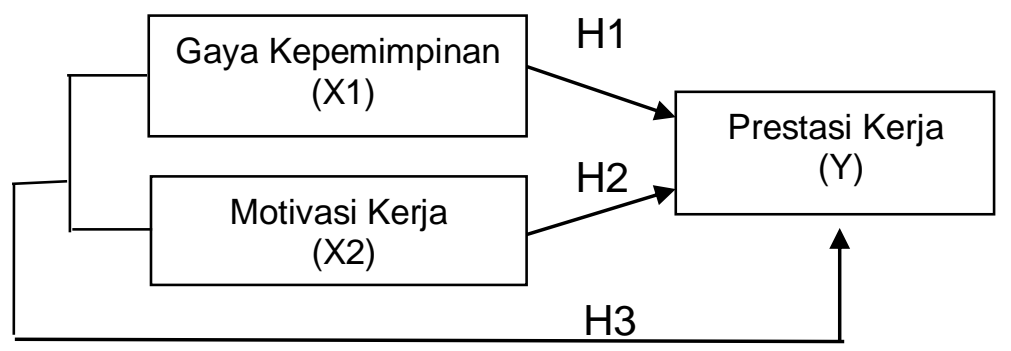

Dari keterangan kerangka pemikiran di atas bahwa gaya kepemimpinan $\left(X_{1}\right)$ berpengaruh terhadap prestasi kerja $(\mathrm{Y})$. Selain itu, motivasi kerja $\left(\mathrm{X}_{2}\right)$ berpengaruh 
terhadap prestasi kerja $(\mathrm{Y})$.dan gaya kepemimpinan $\left(\mathrm{X}_{1}\right)$ dan motivasi kerja $\left(\mathrm{X}_{2}\right)$ secara bersama-samaberpengaruh terhadap prestasi kerja $(\mathrm{Y})$.

\section{METODE PENELITIAN}

Pada penelitian ini yang menjadi objek yaitu pegawai pada Kantor Kecamatan Rawas Ulu, yang beralamatkan di Pasar Surulangun Kecamatan Rawas Ulu Kabupaten Musi Rawas Utara. Pada penelitian menggunakan metode kuantitatif dengan jenis data asosiatif atau kausal yang pengaruh antara variabel independen dan variabel dependenya.

variabel penelitian merupakan sesuatu yang harus diterapkan dan diamati sehingga mendapatkan informasi kemudian dapat menarik kesimpulannya. Maka dalam penelitian tersebut menggunakan 2 variabel yaitu variabel bebas dan variabel terkait, dimana variabel bebas merupakan variabel yang mempengaruhi ialah gaya kepemimpinan dan motivasi kerja. sedangkan variabel terikat merupakan variabel yang akan dipengaruhi yaitu prestasi kerja.

Populasi dalam penelitian ini adalah semua pegawai pada Kantor Kecamatan Rawas Ulu berjumlah 34 orang pegawai di luar dari pemimpin. Pada penelitian ini menggunakan teknik sampel jenuh karena seluruh populasi dijadikan sampel penelitian yang bertotalkan 34 orang pegawai. Dalam penelitian ini sumber data yang digunakan oleh peneliti yaitu data primer yang diperoleh dengan cara membagikan form kuesioner yang berisi serangkaian pertanyaan kepada responden dan dilengkapi dengan data sekunder yaitu dokumen yang diambil dari Kantor Kecamatan Rawas Ulu. Teknik pengumpulan data dalam penelitian ini adalah kuesioner dan dokumentasi. Kuesioner (Angket) merupakan teknik pengumpulan data yang dilakukan dengan cara membagikan form kuesioner yang berisikan serangkaian pertanyaan terhadap responden. Dokumentasi ialah kumpulan data secara tidak langsung melalui file, buku, dan atau majalah. Teknik ini dipergunakan untuk memperoleh data seperti sejarah instansi, struktur instansi, tupoksi instansi.

Pada penelitian ini peneliti menggunakan teknik uji coba instrument data yaitu: uji validitas dan uji reliabilitas uji ini digunakan untuk melihat layak atau tidak layaknya data sebelum melakukan pengujian selanjutnya. Berikut adanya uji asumsi klasik, uji ini digunakan sebagai prasyarat sebelum melakukan teknik analisis data, yaitu: uji normalitas, uji multikoloniearitas dan uji heteroskedastisitas, setelah semua data dinyatakan normal, selanjutnya melakukan teknik analisis data yaitu: analisis regresi linier berganda, analisis koefisien korelasi, analisis koefisien determinasi dan yang terakhir melakukan pengujian hipotesis yaitu uji t (uji parsial) dan uji $F$ (uji simultan).

\section{HASIL PENELITIAN DAN PEMBAHASAN Hasil Uji Validitas Instrumen Variabel Gaya Kepemimpinan}

Hasil Uji Validitas Variabel Gaya Kepemimpinan

\begin{tabular}{|c|c|c|c|}
\hline Item & Pearson Correlation & A & Keterangan \\
\hline Butir 1 & 0,000 & 0,05 & Valid \\
\hline Butir 2 & 0,001 & 0,05 & Valid \\
\hline Butir 3 & 0,035 & 0,05 & Valid \\
\hline Butir 4 & 0,000 & 0,05 & Valid \\
\hline Butir 5 & 0,000 & 0,05 & Valid \\
\hline
\end{tabular}




\begin{tabular}{|c|c|c|c|}
\hline Butir 6 & 0,000 & 0,05 & Valid \\
\hline Butir 7 & 0,000 & 0,05 & Valid \\
\hline Butir 8 & 0,035 & 0,05 & Valid \\
\hline Butir 9 & 0,000 & 0,05 & Valid \\
\hline Butir 10 & 0,017 & 0,05 & Valid \\
\hline
\end{tabular}

Untuk itu dapat dijelaskan pada uji di atas semua pertanyaan dari no 1 sampai 10 pada variabel gaya kepemimpinan diperoleh hasil nilai sig $<\alpha 0,05$ berarti seluruh item pertanyaan dapat dikatakan valid. Dari hal ini dapat diartikan bahwa seluruh butir pertanyaan dari indikator variabel gaya kepemimpinan telah sah untuk dijadikan alat ukur dalam penelitian ini.

\section{Variabel Motivasi Kerja}

\begin{tabular}{|c|c|c|c|}
\hline \multicolumn{4}{|c}{ Hasil Uji Validitas Variabel Motivasi Kerja } \\
\hline Item & Pearson Correlation & A & Keterangan \\
\hline Butir 1 & 0,001 & 0,05 & Valid \\
\hline Butir 2 & 0,000 & 0,05 & Valid \\
\hline Butir 3 & 0,000 & 0,05 & Valid \\
\hline Butir 4 & 0,000 & 0,05 & Valid \\
\hline Butir 5 & 0,000 & 0,05 & Valid \\
\hline Butir 6 & 0,000 & 0,05 & Valid \\
\hline Butir 7 & 0,001 & 0,05 & Valid \\
\hline Butir 8 & 0,000 & 0,05 & Valid \\
\hline Butir 9 & 0,000 & 0,05 & Valid \\
\hline Butir 10 & 0,000 & 0,05 & Valid \\
\hline
\end{tabular}

Dari hasil olahan data diatas diketahui bahwa semua pertanyaan dari item 1 sampai 10 pada variabel motivasi kerja diperoleh hasil nilai sig $<\alpha \quad 0,05$ berarti seluruh item pertanyaan dapat dikatakan valid. Dari hal ini dapat diartikan bahwa seluruh butir pertanyaan dari indikator motivasi telah sah untuk dijadikan alat ukur dalam penelitian ini.

\section{Variabel Prestasi Kerja}

Hasil Uji Validitas Variabel Prestasi Kerja

\begin{tabular}{|c|c|c|c|}
\hline Item & Pearson Correlation & A & Keterangan \\
\hline Butir 1 & 0,034 & 0,05 & Valid \\
\hline Butir 2 & 0,014 & 0,05 & Valid \\
\hline Butir 3 & 0,011 & 0,05 & Valid \\
\hline Butir 4 & 0,008 & 0,05 & Valid \\
\hline Butir 5 & 0,010 & 0,05 & Valid \\
\hline Butir 6 & 0,031 & 0,05 & Valid \\
\hline Butir 7 & 0,000 & 0,05 & Valid \\
\hline Butir 8 & 0,016 & 0,05 & Valid \\
\hline Butir 9 & 0,000 & 0,05 & Valid \\
\hline Butir 10 & 0,001 & 0,05 & Valid \\
\hline
\end{tabular}


Dari hasil olahan di atas di ketahui bahwasemua pertanyaan dari item 1 sampai 10 pada variabel prestasi kerjadiperoleh hasil nilai sig $<\alpha \quad 0,05$ berarti seluruh item pertanyaan dapat dikatakan valid. Dari hal ini dapat diartikan bahwa seluruh butir pertanyaan dari indikator variabel prestasi kerja telah sah untuk dijadikan alat ukur dalam penelitian ini.

\section{Uji Reliabilitas}

\begin{tabular}{|l|c|c|}
\multicolumn{1}{|c|}{ Hasil Uji Reliabilitas Instrumen Gaya Kepemimpinan } \\
\hline \multicolumn{1}{|c|}{ Variabel } & Cronbach's Alpha & Kesimpulan \\
\hline Gaya kepemimpinan & .747 & Reliabel \\
\hline Motivasi kerja & .893 & Reliabel \\
\hline Prestasi kerja & .615 & Reliabel \\
\hline
\end{tabular}

Dari hasil reliabilitas di atas untuk variabel gaya kepemimpinan, motivasi kerja dan prestasi kerja dengan nilai output Cronbach's Alpha $>0,6$ dan dinyatakan reliabel.

\section{Hasil Uji Prasyarat Analisis Data Uji Normalitas}

Hasil Uji Normalitas

One-Sample Kolmogorov-Smirnov Test

\begin{tabular}{|l|l|r|}
\hline \multicolumn{2}{|c|}{} & \multicolumn{1}{|c|}{ Unstandardized Residual } \\
\hline \multirow{2}{*}{ Normal Parameters } & 34 \\
\hline \multirow{2}{*}{ Most Extreme Differences } & Mean & .0000000 \\
\cline { 2 - 3 } & Std. Deviation & 2.16341131 \\
\cline { 2 - 3 } & Absolute & .113 \\
\cline { 2 - 3 } & Positive & .113 \\
\cline { 2 - 3 } & Negative & -.088 \\
\hline \multicolumn{2}{|l|}{ Test Statistic } & .113 \\
\hline Asymp. Sig. (2-tailed) & $.200^{\mathrm{c}, \mathrm{f}}$ \\
\hline
\end{tabular}

Dari olahan data di atas dapat dilihat nilai signifikan (Asymp.Sig 2-tailed) sebesar 0,200.Signifikan lebih dari 0,05 $(0,200>0,05)$, maka dapat disimpulkan data tersebut berdistribusi normal.

\section{Uji Multikoloniearitas}

Hasil Uji Multikoloniearitas
\begin{tabular}{|l|l|r|r|}
\hline \multicolumn{2}{|l|}{ Model } & \multicolumn{1}{c|}{ Tolerance } & VIF \\
\hline 1 & (Constant) & & \\
\hline & $\begin{array}{l}\text { total_gaya } \\
\text { kepemimpinan }\left(\mathrm{X}_{1}\right)\end{array}$ & .846 & 1.182 \\
\hline & total_motivasi kerja $\left(\mathrm{X}_{2}\right)$ & .846 & 1.182 \\
\hline
\end{tabular}

Dari olahan data di atas dapat diketahui nilai Tolerance variabel yaitu variabel gaya kepemimpinan dan motivasi kerja adalah 0,846 berarti $>0,1$ sedangkan VIF bernilai 1,182 berarti < 10. Maka dapat disimpulkan bahwa tidak terjadi masalah multikolonieritas. 


\section{Uji Heteroskedastisitas}

\section{Hasil Uji Heteroskedastisitas}

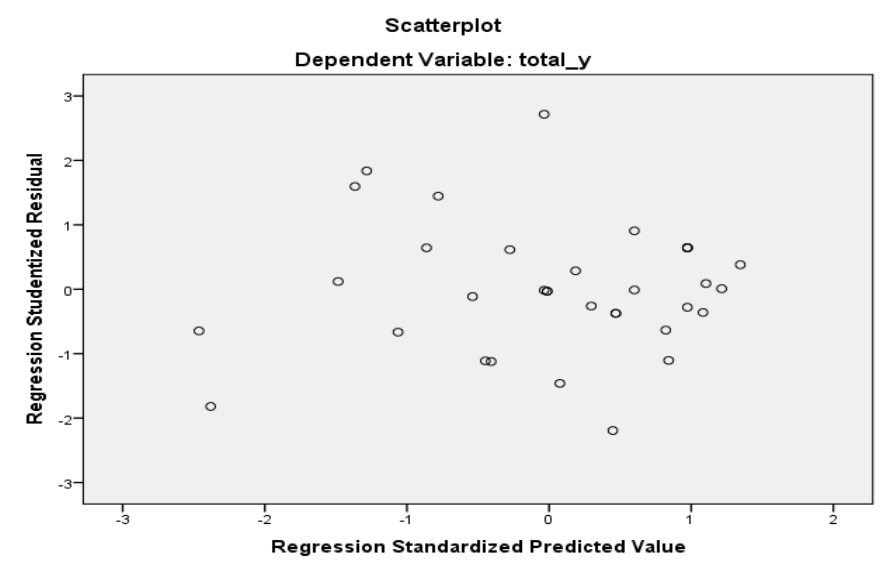

Hasil uji heteroskedastisitas pada grafik di atas tidak ada pola yang jelas, seperti titik-titik menyebar diatas dan dibawah angka 0 pada sumbu Y. Dapat dijelaskan bahwa hasilnya tidak terjadi masalah heterokedastisitas pada model regresi yang digunakan.

\section{Uji Analisis Data}

Uji Analisis Regresi Linier Berganda

Hasil Uji Analisis Regresi Linear Berganda

Coefficients $^{\mathrm{a}}$

\begin{tabular}{|l|l|c|c|c|c|c|}
\hline \multicolumn{2}{|l|}{ Model } & \multicolumn{3}{|c|}{ B Std. Error Beta } & T & Sig. \\
\hline \multirow{3}{*}{1} & (Constant) & 16.127 & 7.608 & & 2.120 & .042 \\
\cline { 2 - 7 } & total_gaya kepemimpinan $\left(X_{1}\right)$ & .377 & .173 & .344 & 2.174 & .037 \\
\cline { 2 - 7 } & total_motivasi kerja $\left(X_{2}\right)$ & .204 & .091 & .357 & 2.252 & .032 \\
\hline
\end{tabular}

Dari perhitungan di atas didapatkan hasil konstanta sebesar 16,127 variabel gaya kepemimpinan $\left(X_{1}\right)$ sebesar 0.377 dan motivasi kerja $\left(X_{2}\right)$ sebesar 0,204 . Maka dapat dirumuskan persamaan regresi linear berganda sebagai berikut :

$\mathrm{Y}=\mathrm{a}+\beta_{1} \mathrm{X}_{1}+\beta_{2} \mathrm{X}_{2}$

$Y=16,127+0,377 X_{1}+0,204 X_{2}$

Sehingga hasil regresi linier berganda di atas dapat diinterpretasikan sebagai berikut:

$\mathrm{a}=16,127$ nilainya positif artinya jika variabel gaya kepemimpinan dan motivasi kerja kerja bernilai 0 maka prestasi kerja sebesar 16,127.

$B_{1}=0,377$ nilainya positif artinya jika gaya kepemimpinan dinaikan sebesar satu satuan dan motivasi kerja dianggap constant maka prestasi kerja pegawai Kantor Kecamatan Rawas Ulu akan meningkat sebesar 0,377 satuan dan sebaliknya jika gaya kepemimpinan diturunkan sebesar satu satuan dan motivasi kerja dianggap constant maka prestasi kerja pegawai Kantor Kecamatan Rawas Ulu akan menurun sebesar 0,377 satuan.

$B_{2}=0,204$, nilainya positif artinya jika motivasi kerja dinaikan sebesar satu satuan dan gaya kepemimpinan dianggap constant maka prestasi kerja pegawai Kantor Kecamatan Rawas Ulu akan meningkat sebesar 0,204 satuan dan 
sebaliknya jika motivasi kerja diturunkan sebesar satu satuan dan gaya kepemimpinan dianggap constant maka prestasi kerja pegawai Kantor Kecamatan Rawas Ulu akan menurun sebesar 0,204 satuan

\section{Uji Analisis Koefisien Korelasi}

\section{Hasil Uji Analisi Koefisien Korelasi} Model Summary

\begin{tabular}{|c|c|c|c|c|c|}
\hline Model & $\mathbf{R}$ & $\begin{array}{c}\mathbf{R} \\
\text { Square }\end{array}$ & $\begin{array}{c}\text { Adjusted } \mathbf{R} \\
\text { Square }\end{array}$ & $\begin{array}{c}\text { Std. Error of the } \\
\text { Estimate }\end{array}$ & Sig. F Change \\
\hline 1 & $.585^{\mathrm{a}}$ & .342 & .300 & 2.23211 & .002 \\
\hline
\end{tabular}

Nilai sig $F$ change $0,002<0,05$ hingga dapat dikatakan bahwa gaya kepemimpinan dan motivasi kerja secara simultan memiliki hubungan yang signifikan terhadap prestasi kerja.

Sedangkan $\mathrm{R}$ (koefisien korelasi) sebesar 0,585 maka dapat dikatakan bahwa tingkat hubungan antara variabel bebas dengan variabel terikat memiliki hubungan yang sedang.

\section{Uji Koefisien Determinasi}

Hasil Koefisien Determinasi Model Summary ${ }^{b}$

\begin{tabular}{|c|c|c|c|c|}
\hline Model & R & R Square & Adjusted R Square & $\begin{array}{c}\text { Std. Error of the } \\
\text { Estimate }\end{array}$ \\
\hline 1 & $.585^{\mathrm{a}}$ & .342 & .300 & 2.23211 \\
\hline
\end{tabular}

Dari olahan data di atas bahwa bahwa besarnya $R$ Square adalah 0.342 atau $34,2 \%$. Artinya kontribusi sumbangan pengaruh variabel bebas gaya kepemimpinan dan motivasi kerja terhadap variabel terikat prestasi kerja yaitu sebesar $34,2 \%$ sedangkan sisanya sebesar $65,8 \%$ disumbangkan oleh faktor-faktor lain diluar penelitian diantaranya kepuasan kerja dan lingkungan kerja

\section{Pengujian Hipotesis} Uji t (Uji Parsial)

Uji t

Coefficients $^{\mathrm{a}}$

\begin{tabular}{|l|l|c|c|c|c|c|}
\hline \multicolumn{2}{|l|}{ Model } & \multicolumn{2}{|c|}{ BStd.Error } & Beta & T & Sig. \\
\hline \multirow{3}{*}{1} & (Constant) & 16.127 & 7.608 & & 2.120 & .042 \\
\cline { 2 - 7 } & total_gaya kepemimpinan $\left(\mathrm{X}_{1}\right)$ & .377 & .173 & .344 & 2.174 & .037 \\
\cline { 2 - 7 } & total_motivasi kerja $\left(\mathrm{X}_{2}\right)$ & .204 & .091 & .357 & 2.252 & .032 \\
\hline
\end{tabular}

Dari hasil di atas menunjukkan signifikan antara variabel gaya kepemimpinan terhadap prestasi kerja bernilai $0,037<0,05$, artinya $\mathrm{H}_{0}$ ditolak Ha diterima, sehingga dapat disimpulkan bahwa secara parsial gaya kepemimpinan berpengaruh signifikan terhadap prestasi kerja pegawai Kantor Kecamatan Rawa Ulu. 
Hasil uji selanjutnya menunjukkan nilai signifikan antara variabel motivasi kerja terhadap prestasi kerja sebesar $0,032<0,05$ artinya $\mathrm{H}_{0}$ ditolak Ha diterima, sehingga dapat disimpulkan bahwa secara parsial motivasi kerja berpengaruh signifikan terhadap prestasi kerja pegawai Kantor Kecamatan Rawas Ulu.

\section{Uji F (Uji Simultan)}

\begin{tabular}{l}
\multicolumn{7}{c|}{$\begin{array}{c}\text { Hasil Uji F } \\
\text { ANOVA }\end{array}$} \\
\begin{tabular}{|l|l|c|c|c|c|c|}
\hline \multirow{2}{*}{ Model } \\
\hline \multirow{2}{*}{1} & $\begin{array}{c}\text { Sum of } \\
\text { Squares }\end{array}$ & Df & $\begin{array}{c}\text { Mean } \\
\text { Square }\end{array}$ & F & Sig. \\
\cline { 2 - 8 } & Regression & 80.284 & 2 & 40.142 & 8.057 & $.002^{\mathrm{b}}$ \\
\cline { 2 - 8 } & Residual & 154.452 & 31 & 4.982 & & \\
\cline { 2 - 8 } & Total & 234.735 & 33 & & & \\
\hline
\end{tabular}
\end{tabular}

Dari hasil uji $\mathrm{F}$ di atas nilai signifikan untuk pengaruh gaya kepemimpinan dan motivasi kerja secara keseluruhan terhadap prestasi kerjaadalah sebesar 0,002 < 0,05. Artinya $\mathrm{H}_{\mathrm{o}}$ ditolak $\mathrm{Ha}$ diterima.Sehingga dapat disimpulkan bahwa gaya kepemimpinan dan motivasi kerja secara simultan berpengaruh signifikan terhadap prestasi kerja pegawai Kantor Kecamatan Rawas Ulu.

\section{Pengaruh Gaya Kepemimpinan Terhadap Prestasi Kerja}

Hasil pengujian hipotesis telah membuktikan terdapat pengaruh antara gaya kepemimpinan terhadap prestasi kerja pegawai. Melalui uji t (uji parsial) didapat nilai signifikan sebesar 0,037 $<0,05$ berarti $\mathrm{H}_{\circ}$ ditolak, $\mathrm{H}_{a}$ diterima, dengan demikian membuktikan bahwa gaya kepemimpinan berpengaruh signifikan terhadap prestasi kerja pegawai Kantor Kecamatan Rawas Ulu

Hasil penelitian ini sejalan dengan penelitian terdahulu Widiartana (2016) yang menyatakan bahwa gaya kepemimpinan berpengaruh secara sigifikan terhadap prestasi kerja karyawan. Dan penelitian lain yang dilakukan oleh Liawati (2013) yang menunjukkan hasil bahwa terdapat pengaruh positif dan signifikan gaya kepemimpinan terhadap prestasi kerja pegawai.

\section{Pengaruh Motivasi Kerja Terhadap Prestasi Kerja}

Hasil pengujian hipotesis telah membuktikan terdapat pengaruh antara motivasi kerja terhadap prestasi kerja pegawai. Melalui uji t (uji parsial) didapat nilai signifikan sebesar 0,032 < 0,05 berarti Ho ditolak, Ha diterima, dengan demikian membuktikan bahwa motivasi kerja berpengaruh signifikan terhadap prestasi kerja pegawai Kantor Kecamatan Rawas Ulu.

Hasil penelitian ini sejalan dengan penelitian terdahulu Widiartana (2016) yang menyatakan bahwa gaya kepemimpinan berpengaruh secara sigifikan terhadap prestasi kerja karyawan. Dan penelitian lain yang dilakukan oleh Liawati (2013) yang menunjukkan hasil bahwa terdapat pengaruh positif dan signifikan gaya kepemimpinan terhadap prestasi kerja pegawai.

\section{Pengaruh Gaya Kepemimpinan dan Motivasi Kerja Terhadap Prestasi Kerja Pegawai}

Berdasarkan nilai $\mathrm{R}$ Square sebesar 0,342 atau $34,2 \%$ artinya kontribusi sumbangan pengaruh variabel gaya kepemimpinan dan motivasi kerja terhadap 
prestasi kerja yaitu sebesar $34,2 \%$ sedangkan sisanya sebesar $65,8 \%$ disumbangkan oleh faktor-faktor lain diluar penelitian diantaranya kepuasan kerja dan lingkungan kerja, dan dapat dilihat juga melalui uji $F$ (Simultan) dengan nilai signifikan sebesar 0,002 < dari 0,05 berarti Ho ditolak, Ha di terima sehingga dapat dijelaskan bahwa gaya kepemimpinan dan motivasi kerja secara simultan berpengaruh signifikan terhadap prestasi kerja.

Hasil penelitian ini sejalan dengan penelitian terdahulu Widiartana (2016) yang menyatakan bahwa gaya kepemimpinan berpengaruh secara sigifikan terhadap prestasi kerja karyawan. Dan penelitian lain yang dilakukan oleh Liawati (2013) yang menunjukkan hasil bahwa terdapat pengaruh positif dan signifikan gaya kepemimpinan terhadap prestasi kerja pegawai.

\section{E. KESIMPULAN DAN SARAN}

\section{1) Kesimpulan}

Berdasarkan hasil yang diperoleh penelitian ini, dan hasil pembahasan yang telah dilakukan dan diuraikan pada babsebelumnya, maka kesimpulan yang dapat dikemukakan oleh penulis dalam penelitian ini sebagai berikut:

a) Ada pengaruh yang signifikan antara gaya kepemimpinan $\left(X_{1}\right)$ dengan motivasi kerja $\left(X_{2}\right)$ secara bersama-sama terhadap prestasi kerja $(Y)$ Kantor Kecamatan Rawas Ulu.

b) Secara parsial, gaya kepemimpinan $\left(\mathrm{X}_{1}\right)$ berpengaruh signifikan terhadap prestasi Kerja (Y) Kantor Kecamatan Rawas Ulu.

c) Secara parsial, motivasi kerja $\left(\mathrm{X}_{2}\right)$ berpengaruh signifikan terhadap prestasi kerja pegawai (Y) Kantor Kecamatan Rawas Ulu.

\section{2) Saran}

Berdasarkan kesimpulan yang telah diuraikan, maka saran yang dapat peneliti sampaikan adalah sebagai berikut:

a) Gaya kepemimpinan di instansi sudah cukup baik untuk menciptakan prestasi kerja, oleh karena itu diharapkan kepada pimpinan agar mampu meningkatkan tanggung jawabnya sebagai pemimpin, dengan memotivasi, membimbing serta mengarahkan karyawanya ke arah yang lebih baik, sehingga dapat terciptanya prestasi kerja yang lebih baik lagi.

b) Gaya Kepemimpinan memiliki pengaruh cukup besar dalam meningkatkan prestasi kerja, oleh karena itu seorang pemimpin harus mampu memberikan motivasi kepada bawahannya, seandainya motivasi kerja pegawai sendiri rendah maka pemimpin harus dapat meningkatkannya yaitu lewat pendekatan hubungan interpersonal yang baik dengan pegawai, disamping itu pimpinan selalu memberikan suri teladan kepada pegawainya, seperti kedisiplinan, perilaku, dan sebagainya. Agar karyawan menyadari adanya kebutuhan psikologis dan berusaha untuk memenuhinya sehingga akan meningkatkan prestasi kerja.

c) Terkadang masih ada beberapa yang menjadi penyebab menurunya prestasi karyawan, oleh karena itu pemimpin harus mampu memotivasi karyawannya dengan cara memberikan penghargaan serta mendengarkan dan menghargai ide-ide yang diberikan oleh karyawan dan tidak mengkritik yang bersifat menyinggung sehingga dapat menurunkan motivasi karyawan. 


\section{DAFTAR PUSTAKA}

Busro, M. (2018). Teori-Teori Manajemen Sumber Daya Manusia. Jakarta: Prenadamedia Group.

Desler. (2015). Manajemen Sumber Daya Manusia . Jakarta: Salemba Empat.

Hasibuan, M. S. (2017). Manajemen Sumber Daya Manusia. edisi ketujuh jakarta: Penerbit PT. Bumi Aksara.

Husnan,R.D. (2011). Manajemen Personalia. edisi ke empat. Yogyakarta: BPFE.UGM.

Kartono. (2016). Pemimpin dan Kepemimpinan, Apakah Kepemimpinan Abnormal itu? . (cetakan ke-21). Jakarta: Rajawali Pers.

Kholilah. (2018). Perilaku Organisasi. Cetakan Pertama. Palembang: Perpustakaan Nasional Katalog dalam Terbitan (KDT).

Liawati, D. A. (2013). Pengaruh Gaya Kepemimpinan dan Motivasi Kerja Terhadap Prestasi Kerja Pegawai pada Kantor Wilayah Direktorat Jendral Perbendaharaan Provinsi D.I. Yogyakarta. Universitas Negeri Yogyakarta.

Mulyadi. (2015). Akuntansi biaya. Edisi 5. Yogyakarta: Sekolah Tinggi IImu Manajemen YKPN.

Puspitasari, S. d. (2014). Pengaruh Motivasi Kerja dan Pelatihan Kerja Terhadap Kinerja Karyawan Pada Kantor Pelayanan Pajak Pratama.

Rivai Z. V. (2017). Manajemen Sumber Daya Manusia untuk Perusahaan dari Teori ke Praktek. Jakarta : Pt Raja Granindo Persada.

Siagian, S. P. (2015). Manajemen Sumber Daya Manusia. Jakarta: PT Bumi Aksar.

Sikula, A. F. (2015). Manajemen Sumber Daya Manusia. Bandung: Erlangga.

Winardi, J. (2014). Teori Organisasi dan Pengorganisasian. Jakarta: Rajawali Press.

Widiartana, W. (2016). Pengaruh Gaya Kepemimpinan dan Motivasi Kerja Terhadap Prestasi Kerja Karyawan pada UD. Sinar Abadi. Jurnal Program Studi Pendidikan Ekonomi, Vol: 6 Nomor:1tahun 2016.

Yoder, D. (2015). Manajemen Sumber Daya Manusia. Erlangga:Bandung. 